\title{
Psychological well-being of Ghanaian children in transnational families
}

Citation for published version (APA):

Mazzucato, V., \& Cebotari, V. (2017). Psychological well-being of Ghanaian children in transnational families. Population Space and Place, 23(3), [2004]. https://doi.org/10.1002/psp.2004

Document status and date:

Published: 01/04/2017

DOI:

10.1002/psp.2004

Document Version:

Publisher's PDF, also known as Version of record

Document license:

Taverne

Please check the document version of this publication:

- A submitted manuscript is the version of the article upon submission and before peer-review. There can be important differences between the submitted version and the official published version of record.

People interested in the research are advised to contact the author for the final version of the publication, or visit the DOI to the publisher's website.

- The final author version and the galley proof are versions of the publication after peer review.

- The final published version features the final layout of the paper including the volume, issue and page numbers.

Link to publication

\footnotetext{
General rights rights.

- You may freely distribute the URL identifying the publication in the public portal. please follow below link for the End User Agreement:

www.umlib.nl/taverne-license

Take down policy

If you believe that this document breaches copyright please contact us at:

repository@maastrichtuniversity.nl

providing details and we will investigate your claim.
}

Copyright and moral rights for the publications made accessible in the public portal are retained by the authors and/or other copyright owners and it is a condition of accessing publications that users recognise and abide by the legal requirements associated with these

- Users may download and print one copy of any publication from the public portal for the purpose of private study or research.

- You may not further distribute the material or use it for any profit-making activity or commercial gain

If the publication is distributed under the terms of Article $25 \mathrm{fa}$ of the Dutch Copyright Act, indicated by the "Taverne" license above, 


\title{
Psychological Well-being of Ghanaian Children in Transnational Families
}

\author{
Valentina Mazzucato ${ }^{1, *}$ and Victor Cebotari ${ }^{2}$ \\ ${ }^{1}$ Department of Technology \& Society Studies, Maastricht University, Maastricht, The Netherlands \\ ${ }^{2}$ Maastricht Graduate School of Governance, Maastricht University, Maastricht, The Netherlands
}

\section{ABSTRACT}

This study is one of the first large-scale analyses on child psychological well-being in the context of parental migration when children remain in an African country. As such, it contributes to the literature by investigating some of the insights gained from in-depth transnational family studies, and it also provides evidence from Africa where normative contexts around family life differ from Latin America, Southeast Asia, and East Asia where most studies have been conducted to date. A survey was conducted in $2010 / 2011$ with 2,760 secondary school children and youths in high out-migration areas of Ghana. Using multiple regression analysis, we find that being in a transnational family is associated with lower levels of psychological well-being, yet only in families where parents are divorced or separated. Furthermore, when parents are in a relationship, specific characteristics of transnational family arrangements are associated with lower levels of child psychological well-being, while others are not. In particular, whether a parent migrates internally or internationally, who the caregiver is, and having a good relationship with the migrant parent are not associated with poorer well-being outcomes. Instead, if a father migrates, if the child changes caregivers more than once, and if the child has a bad relationship with his or her migrant father are associated with lower levels of well-being. This study adds nuance to a field of research that has emphasised negative outcomes and helps identify policy areas to improve the well-being of children in transnational families. Copyright (c) 2016 John Wiley \& Sons, Ltd.

*Correspondence to: Valentina Mazzucato, Department of Technology \& Society Studies, Maastricht University, Maastricht, The Netherlands.

E-mail: v.mazzucato@maastrichtuniversity.nl
Accepted 19 October 2015

Keywords: migration; transnational families; child psychological well-being; Africa; Ghana

I nternational migration often involves the creation of transnational families in which one member migrates to another country while other members remain in the country of origin. Especially in migration from the Global South to the North, such transnational family situations emerge as a consequence of strict migration policies in destination countries that make it difficult to migrate as a family. In other instances, these situations are the preferred choice of family members. This leaves families to organise one of the basic functions of the family, that is, care, transnationally. How families do so and the effects this has on the individual family members have been the focus of transnational family studies since the turn of the century (Mazzucato \& Schans, 2011). More recently, literature on transnational social protection focuses on the formal and informal strategies that families adopt to secure the welfare of all their members, both at home and abroad, giving rise to new forms of inequalities within families (Dankyi et al., 2016; Faist et al., 2015). Studies have focused primarily on migrant parents and their children (Dreby, 2007; Parreñas, 2005; Schmalzbauer, 2004), spousal relationships (Pribilsky, 2004), and to a lesser extent on migrant adult children and their elderly parents (King et al., 2014). Through in-depth cases, these studies have shown that families continue to operate even across great distances and over long periods of time, and they highlight the challenges that migrants and their family members back home face in maintaining active and healthy relationships. Yet, there are some gaps in knowledge that need addressing. While negative emotional consequences have been found to prevail among children and parents in transnational families, it is not yet known if such emotional consequences affect 
people's overall well-being outcomes. Furthermore, because studies are generally small in scale, it is difficult to discern whether there are other characteristics about transnational families that may be driving the negative results, rather than the separation of family members, as is currently posited.

This study aims to contribute to transnational family studies by analysing on a large scale the effects of parental migration on the psychological well-being of children and youths who remain in Ghana. As such, we compare children in transnational families with those who live with both of their parents in Ghana in order to understand how transnational family dynamics may differ from those of non-transnational families, something that has not yet been carried out in the indepth cases of transnational family studies. We analyse primary data collected in 2010/2011 from a sample of Ghanaian school children and youths between the ages of 11 and 21 years. This study refers to the target population as children to emphasise the type of relationship they have with the migrant parent abroad.

We draw upon child psychology and family sociology studies, which have recently considered the well-being of children in transnational families using large-scale datasets. Generally, these studies confirm qualitative transnational family studies showing that these children experience more psychological challenges than those without migrant parents (Jordan \& Graham, 2012; Wen \& Lin, 2012). However, these studies also find confounding factors such as individual attributes, family environments, and community contexts (Fan et al., 2010; Glick, 2010) that also influence children's overall levels of well-being. This therefore begs the question whether it is separation per se that drives negative outcomes or whether there are other factors that can help explain poor well-being outcomes.

Transnational families are diverse, yet only few of the child psychology and family sociology studies take into consideration the multiplicity of characteristics of transnational families (Mazzucato, 2015). We address the gap identified by Wall and Bolzman (2014) of needing to take the diversity of transnational families into account, by systematically investigating characteristics that have been identified in the qualitative transnational family literature and new characteristics that we draw from child psychology and family sociology studies but that have not yet

Copyright (c) 2016 John Wiley \& Sons, Ltd. been analysed in the context of transnational families. By analysing these characteristics on the same sample, we can observe which aspects of transnational care arrangements are associated with poorer child psychological well-being, adding precision to the analysis of transnational families.

This study is one of the first large-scale analyses of the effects of parental migration on children in an African context (Mazzucato et al., 2015). Subsequently, we discuss this context and why it may significantly contribute to the study of the effects of migration on child well-being.

\section{BACKGROUND}

\section{Ghanaian Migration and Transnational Families}

Split families as the result of migration are not a new phenomenon in Ghana, which has a long history of people travelling throughout the country, the West African region, and beyond for commerce and other economic activities. Large-scale migration to the Global North began in the early 1980s when economic stagnation in Ghana coupled with large numbers of Ghanaians being expulsed from Nigeria resulted in many Ghanaians migrating to Europe and beyond in search of a living (Peil, 1995). Since then, Ghana has been the origin country of some of the largest populations of Africans living in the West, including the US, the UK, Germany, Italy, and the Netherlands.

In Ghana, family systems are characterised by norms of social parenthood in which more than just the biological parents are involved in the raising of a child, and the practice of child fostering, in which a child is entrusted to another family member to be raised, irrespective of parental migration (Goody, 1982). This is a different cultural context than the Philippines and Latin America where most transnational family studies have been conducted, where the ideology of the nuclear family is strong (Coe, 2011; Fog Olwig, 2014). In Ghana, it is estimated that approximately $18 \%$ of children up to 14 years old, excluding orphans, were fostered in 2008 (GDHS, 2008). While these numbers do not only pertain to children with migrant parents, they indicate the existence of a normative context of being raised by people other than one's biological parents, which may influence

Popul. Space Place 2017; 23: e2004 DOI: $10.1002 / p s p$ 
the way children will experience their parents' migration.

\section{Transnational Families and the Well-being of Children}

Transnational migration studies were the first to focus specifically on families living across borders. In these studies, the problem of children 'left behind' became a scholarly focus. Children can feel abandoned and react by detaching themselves emotionally from their parent (Dreby, 2007) or expressing severe anger, feelings of being unloved, or worry (Parreñas, 2005). Such feelings can lead to unwanted behaviour, such as dropping out of school or gang involvement (Smith, 2006). Recently, a growing number of family and child psychology studies have picked up on this theme and have investigated the effects of parent-child separation on children who are left in the home country or region. These studies indicate that children experience a decline in mental health and exhibit more psychopathology, and less pro-social behaviour (Fan et al., 2010), in addition to poorer health behaviour and engagement in school (Wen \& Lin, 2012). These studies also stress that migration can disrupt parent-child bonding (Smith et al., 2004) and that reunification does not necessarily restore the relationship (Suarez-Orozco et al., 2002).

Transnational family studies focus predominantly on mother-child separation and emphasise the emotional distress that mothers experience as the result of separation from their children and the psychological and behavioural consequences for the children (Dreby, 2007; Schmalzbauer, 2004). Furthermore, studies argue that separation from a mother tends to have greater negative psychological consequences than separation from a father (Parreñas, 2005). Migration of a mother has been shown to negatively affect the level of happiness and overall psychological status of children in Asia (Jordan \& Graham, 2012; Wen \& Lin, 2012). Yet, there is still too little evidence from large-scale studies to be able to conclude that maternal migration is always associated with worse psychological outcomes for children, as this has only started to be investigated.

Parental marital status has hardly been investigated in large-scale transnational family studies. Yet, we know from studies on divorce that do not focus on migrant families that divorce and separation negatively affect child well-being (Bzostek \& Beck, 2011; Amato \& Cheadle, 2005). Despite this evidence, most large-scale transnational family studies restrict their samples to families in which couples are in a relationship in order to isolate the effects of migration on child well-being. In one of the few studies that looks explicitly at marital relationships and migration, Nobles (2011) finds that parental migration and parental divorce are substantially distinct experiences and that separation due to divorce has a worse impact on children than separation due to migration. Parents who separate may not have the necessary resources to invest in children, especially if they have formed new families abroad (Dreby, 2010).

Migration has been also found to strain spousal relationships (Pribilsky, 2004), which could be one of the pathways in which migration may negatively impact children's well-being. In other instances, migration may be a way to escape a problematic spousal relationship (Constable, 2003). While these two dynamics are difficult to extricate from each other methodologically, these studies point to the need to analyse the effects of couple separation on children in transnational families.

Most of the child development studies on transnational families have been conducted in China and therefore deal with internal migration, albeit over very large distances. The qualitative transnational family studies, instead, for the most part, pertain to migration between the Americas or from Southeast Asia and thus relate to international migration. Yet, no study to our knowledge compares the effects of parental migration between internal and international migrations. There are reasons to believe that these two types of migrations will have different effects. Attachment theory (Bowlby, 1973) used in child psychology literature explains that for a good relationship to develop between a child and a caregiver, close proximity needs to be ensured. Thus, large geographical distances entailing bureaucratic and administrative boundaries and higher financial costs will impede parents from seeing their children as often as parents who have migrated internally and thus are anticipated to lead to poorer well-being for children. Furthermore, there are different expectations regarding the two types of migrations regarding reunification (Graham \& Jordan, 2011: 766) and material benefits (Mazzucato, 2011), with international migration associated with 
greater expectations. The difficult situations that many migrant parents face overseas can easily lead to unmet expectations (Poeze \& Mazzucato, 2014) and can result in worse well-being for children.

The caregiver's role in the well-being of children is conceptually important but largely understudied (Mazzucato \& Schans, 2011). When adapting to new care arrangements, children must form new attachments (Schmalzbauer, 2004) and accept new authority figures (Smith et al., 2004). Caregivers can influence how children perceive their parents' migration by speaking frequently to the children about their parents (Dreby, 2007). Additionally, as shown earlier, in Ghana, as in many parts of Africa, child fostering is commonly practiced, setting a normative context for being cared for by others than biological parents. Contemporary forms of fostering are primarily practiced with close kin (grandparents, aunts, and uncles).

No study on transnational families to our knowledge has investigated the frequency with which children change caregivers, or what we call the stability of the caregiving arrangement. Family and child psychology literatures focusing on family process not specifically related to migration have highlighted the importance of a stable caregiver for children. Changes in caregivers are found to lead to poorer well-being for children (Amato \& Cheadle, 2005) as is family instability because of divorce (Bzostek \& Beck, 2011). Boynton-Jarrett et al. (2013) find that family structure disruptions are associated with greater exposure to violence and more risky health behaviours and greater mental health problems among adolescents. These findings warrant an investigation of the effects of caregiver stability in the case of transnational families.

The quality of the relationship migrant parents are able to maintain with their children is also important for the well-being of the child. Children who feel cared for and who have regular contact with their migrant parents through telephone calls and other information and communication technologies have greater understanding for their parents' migration and see them as sacrificing themselves for their good (Dreby, 2007). These children express having a good relationship with their parents and as a consequence do not harbour resentment towards them nor feelings of abandonment (Poeze \& Mazzucato, 2014). We therefore investigate the quality of the relationship children report having with their migrant parent.

Based on the aforementioned findings, we investigate five transnational family characteristics to take into account the diversity in transnational families. These five characteristics are as follows: which parent has migrated; the location of the migrant parent; the relationship type of the caregiver; the stability of the child-raising arrangement; and the quality of the relationships between the child and migrant parent.

\section{DATA AND METHOD}

\section{Data and Sample}

This analysis is based on a survey conducted in 2010/2011 among secondary school children in Ghana $(N=2,760)$ in areas with high outmigration rates: the greater Accra region, Kumasi, Sunyani, and Cape Coast. The sample is composed of children living with both biological parents and those who have at least one parent who has migrated internally or internationally. The data contain over 190 indicators pertaining to children's socio-economic, transnational family, and school characteristics, in addition to educational, health, and psychological well-being outcomes. The questionnaire was administered as a self-reporting tool, completed by students under the guidance and supervision of the surveying team.

A stratified sampling procedure was used to select children from low-quality and high-quality and public and private schools in each surveyed area. Twenty-two schools were randomly selected within these categories across junior and secondary schools. The Department of Education in Ghana divides public and private schools into different quality categories based on exam scores and student enrolment. Key informants were asked to conduct a similar categorisation of private international schools. Permission was asked from schools, all of which accepted to be surveyed, except for one, which was replaced by another randomly selected school. In each selected school, a class was randomly selected from each of the three grades in addition to another randomly selected classroom. In addition, purposive sampling was used to select a sufficient number of children in transnational families. All students were informed of the project and the voluntary 
nature of their involvement. The average student response rate in our sample was $85 \%$. This sampling resulted in a total of 2,760 students ranging between the ages of 11 and 21 years.

The analytical sample of our study is composed of children with at least one parent away internationally and children living with both biological parents. Only one indicator comparing the internal and international location of the absent parent (see succeeding text) additionally includes children with one or both parents who migrated internally. Children with at least one parent deceased $(N=183)$ and those who could not indicate the location of their parents $(N=50)$ were excluded from the analytical sample.

\section{Variables}

Child psychological well-being is measured with the 20-item total difficulties score (TDS) of the Strength and Difficulties Questionnaire (SDQ), a validated behavioural screening tool covering children's behaviour, emotions, and peer relations (Goodman, 1997). The SDQ has been translated into more than 60 languages and used in different contexts worldwide, with acceptable reliability and validity scores (Palmieri \& Smith, 2007). The SDQ comprises 25 questions that are grouped into five indexed factors: emotional symptoms (e.g. I have many fears); conduct problems (e.g. I get very angry and lose my temper); hyperactivity (e.g. I am restless; I cannot sit still); peer issues (e.g. other children my age like me); and a pro-social scale (e.g. I usually share with others). All indexed factors except for the pro-social scale are added to generate the TDS $(0-40)$ that is employed in this study (Goodman et al., 2000). For the current analysis, the internal consistency of the TDS scale (Cronbach's $\alpha=0.72$ ) and its four subscales (Cronbach's $\alpha=0.70-0.73$ ) was tested and found to be good. The TDS is measured as an indexed linear scale to capture the dispersed variation of indicators explaining the latent factors as revealed by a principal component factor analysis.

We measure transnational families in different ways to consider the variety in transnational families. The most basic is whether a child has at least one parent who has migrated internationally. Additionally, in this measure, we consider the relationship between the parents by further distinguishing between children in transnational families with divorced/separated parents and children in transnational families with parents in a relationship.

We also distinguish families by which parent migrates: children who have a migrant father abroad and are cared for by the mother, those who have a migrant mother abroad and are cared for by the father, and those whose both parents are migrants and are cared for by a non-biological parent. These three groups are compared with children who live with both of their parents in Ghana.

The location of parental migration is composed of three categories of children: those who live with both parents; those with no internationally migrated parent but with at least one internally migrated parent; and those with at least one internationally migrated parent. This is the only indicator in which we also include children who have at least one internally migrated parent (and no international migrant parent).

The relationship type of the child's caregiver may also vary in transnational families. In this measure, we distinguish by who the caregiver is: both parents, the 'stay behind' parent, an uncle or aunt, a grandparent, and others. This last category regroups children who are cared for by categories of caregivers who were too few to analyse separately such as other kin, non-kin, or themselves.

The stability of the child-raising arrangement is measured through four categories indicating the number of times children changed caregivers: live with both parents and never changed caregiver; live with both parents and changed caregiver one or more times; live in a transnational family and never changed caregiver; and live in a transnational family and changed caregiver one or more times.

The quality of the relationship between children and their migrant parents is measured similarly to the Child Health and Migrant Parents in Southeast Asia study (Graham \& Jordan, 2011). We asked children: 'When something is bothering or troubling me, I can turn to my mother/father for help'. Children could answer on a 5-point Likert scale ranging from 'never' to 'always'. A binary variable was created with the first three answers representing a 'bad' relationship and the last two representing a 'good' relationship. We categorised answers for mothers and fathers separately and included three categories: those 
who live with both of their parents and said to have a good relationship with their mother/father as the reference category; those who have a good relationship with their migrant mother/father; and those who have a bad relationship with their migrant mother/father.

A group of controls used relates to child demographics. We categorised children into three age groups: younger children (11-14 years), adolescents (15-17 years), and older children (18-21 years). We include a gender variable as girls tend to report lower psychological wellbeing than boys. Because of the high ethnic diversity of Ghanaian society, ethnicity was also included as a control variable with the majority Akan being the reference category. A second group of indicators relates to parental and familial characteristics. One indicator measures the highest level of education achieved by either of the parents. Educational status was coded some/finished primary education, some/finished secondary education, some/finished vocational education, and some/finished tertiary education. The analysis also includes an indicator of parents' age: $\leq 39$, $40-49$, and $\geq 50$ years. Each age category records the age of the oldest parent. The presence of the total number of siblings living with the child is also considered in the analysis.

A third group of indicators describes the general living conditions of the child. Children were asked to assess their living conditions: 'Compared to other children, would you say that your living conditions are better, the same, or less good'. A second indicator is employed to measure housing conditions by dividing the total number of people living in the home by the total number of rooms available in the home.

A fourth group of indicators includes schooling conditions. These conditions are defined by school ranking: low or high and public or private. In Ghana, there are large differences in the quality of education and resources available for students according to the mixture of rank and public/private characteristics of schools, with highly ranked public schools offering some of the best education and resources to students. School types have not featured prominently in research on children's psychological well-being and parental migration. However, Wen and Lin (2012) find that support received from the school and teachers has positive effects on children's wellbeing outcomes.

\section{Analytical Strategy}

The analysis is conducted in two stages. The first stage compares descriptive statistics of the dependent variable according to different transnational family characteristics (Table 1). We conduct analysis of variance tests to assess if there are statistically significant differences between the sub-categories of each transnational family characteristic. Next, we examine if there is a relationship between being in a transnational family and children's psychological well-being in Ghana, by taking the most basic measure of a transnational family, whether a child has at least one parent who has migrated internationally, and take into consideration whether the parents are married/together or divorced/separated. We use a multiple regression technique to examine the association (Table 2), in which we successively control for child demographics (Model 2), family characteristics (Model 3), living conditions (Model 4 ), and school type indicators (Model 5).

In a second stage, we explore whether the effects of international parental migration found in the full model (Model 5 in Table 2) of the previous analysis holds true if different characteristics of transnational families are considered. Because we want to separate the effects of migration from those of marital dissolution, this stage of analysis excludes those children whose parents are separated and their parents have migrated internally $(N=392)$ or internationally $(N=175)$. Table 3 presents results for the five transnational child-raising characteristics explored in subsequent models (Models 6-10b) while controlling for the same set of indicators as in Table 2. Each model was explored by adding controls in a step-wise fashion, but for space reasons, we only present the results of the full models.

The analysis employs ordinary least squares regressions with robust standard errors using the Hubert-White sandwich estimators. All models control for missing data by including a category for 'missing' for the age and education of parents (not reported in the tables) as documented by Case et al. (2005). The independent indicators were tested for multicollinearity, and none was found. A multilevel modelling approach was initially considered, but the low intraclass correlation estimates showed limited variance (below 0.10) at the child level when 
Table 1. Means (standard deviations) of different transnational characteristics by psychological well-being (TDS).

\begin{tabular}{|c|c|c|c|}
\hline \multirow[b]{2}{*}{ Types of transnational care } & \multicolumn{3}{|c|}{ Psychological well-being (TDS) ${ }^{\mathrm{a}}$} \\
\hline & $\mathrm{N}$ & & \\
\hline International parental migration & & \multicolumn{2}{|c|}{$F(2,1374)=7.75^{* * *}$} \\
\hline Live with both parents & 953 & 11.3 & (5.4) \\
\hline Parents away internationally: in a relationship & 275 & 11.5 & $(5.8)$ \\
\hline Parents away internationally: separated/divorced & 149 & 13.2 & (5.5) \\
\hline Total $N$ & 1,377 & & \\
\hline Who is the migrant parent & & \multicolumn{2}{|c|}{$F(3,1161)=0.71$} \\
\hline Live with both parents & 1,125 & 11.1 & (5.3) \\
\hline Father away and mother caregiver & 221 & 11.6 & (5.9) \\
\hline Mother away and father caregiver & 47 & 12.1 & (5.9) \\
\hline Both parents away and other caregiver & 116 & 11.4 & (5.4) \\
\hline Total $N$ & 1,509 & & \\
\hline Location migrant parent(s) & & \multicolumn{2}{|c|}{$F(2,1898)=0.20$} \\
\hline Live with both parents & 1,232 & 11.3 & (5.4) \\
\hline Parent(s) away nationally & 331 & 11.5 & (5.5) \\
\hline Parent(s) away internationally & 364 & 11.5 & (5.7) \\
\hline Total $N$ & 1,927 & & \\
\hline Caregiver & & \multicolumn{2}{|c|}{$F(4,1143)=0.41$} \\
\hline Live with both parents & 1,141 & 11.2 & (5.4) \\
\hline Caregiver: one parent & 246 & 11.5 & (5.8) \\
\hline Caregiver: uncle/aunt & 39 & 11.6 & (5.2) \\
\hline Caregiver: grandparent & 28 & 10.0 & (5.4) \\
\hline Caregiver: other & 36 & 11.6 & (5.5) \\
\hline Total $N$ & 1,490 & & \\
\hline Stability of the care arrangement & & \multicolumn{2}{|c|}{$F(3,1092)=3.83^{* * *}$} \\
\hline Live with both parents: changed never & 823 & 11.0 & (5.3) \\
\hline Live with both parents: changed caregiver $\geq 1$ & 244 & 12.5 & (5.6) \\
\hline Transnational: never changed caregiver & 177 & 11.3 & (6.2) \\
\hline Transnational: changed caregiver $\geq 1$ & 155 & 11.9 & (5.4) \\
\hline Total N & 1,399 & & \\
\hline Quality of the child-mother relationship & & \multicolumn{2}{|c|}{$F(2,696)=0.83$} \\
\hline Live with both parents: good & 778 & 10.5 & (5.1) \\
\hline Migrant mother: good & 56 & 10.7 & (5.1) \\
\hline Migrant mother: bad & 51 & 11.6 & (5.1) \\
\hline Total $N$ & 885 & & \\
\hline Quality of the child-father relationship & & \multicolumn{2}{|c|}{$F(2,650)=2.56$} \\
\hline Live with both parents: good & 579 & 10.5 & (5.3) \\
\hline Migrant father: good & 133 & 10.6 & (5.6) \\
\hline Migrant father: bad & 115 & 11.9 & (5.1) \\
\hline Total N & 827 & & \\
\hline
\end{tabular}

Analysis of variance was used for all comparisons. The numbers are the reported mean values; standard deviations are in parentheses.

TDS, total difficulties score.

${ }^{a}$ The TDS has values between 0 and 40, with higher numbers denoting more psychological distress.

${ }^{*} p<0.05$.

${ }^{* *} p<0.01$.

${ }_{* * *} p<0.001$.

schools or cities were considered at the second level. However, indicators for the quality and type of schools were included to account for the unobserved characteristics that may arise at the school level.

\section{RESULTS}

For brevity, we only discuss descriptive results pertaining to the dependent variable, psychological well-being. Children with migrant parents 


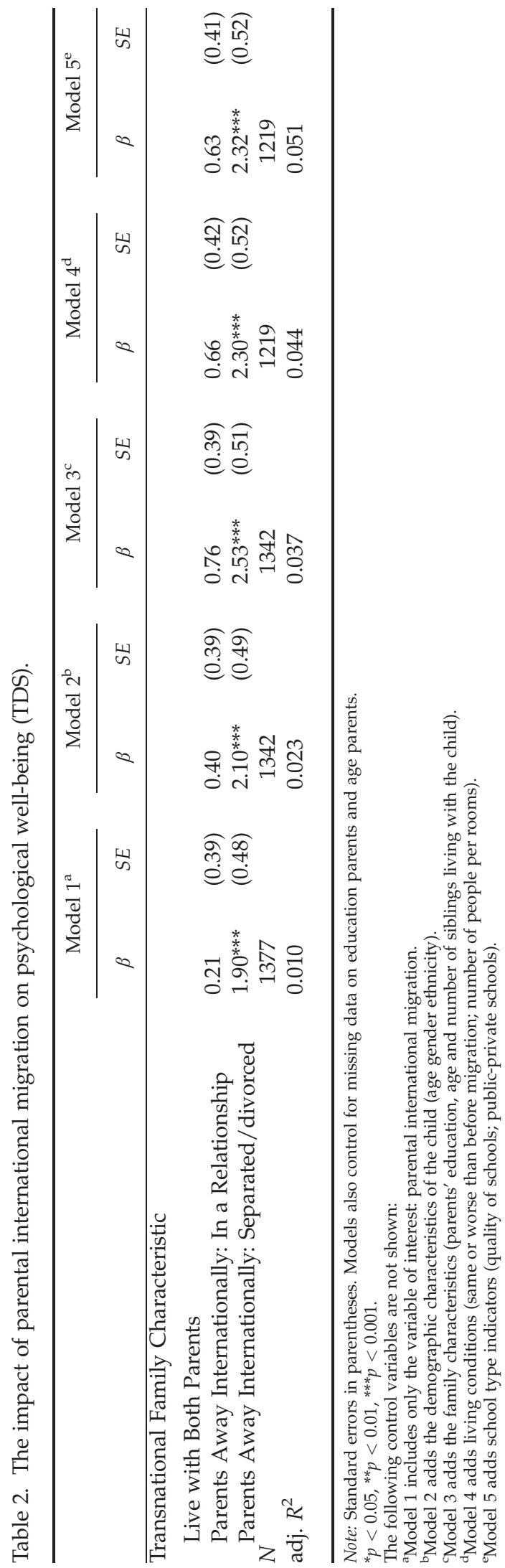

have slightly more psychological distress than children living with both parents, particularly when parents are separated/divorced, the mother migrates, the child frequently changes caregivers, or the child has a bad relationship with his or her parents (Table 1). Children who are being cared for by their grandparents and those having a good relationship with their migrant parents show less psychological distress.

Table 2 shows that being in a transnational family where parents are in a relationship does not significantly impact the psychological wellbeing of children. Conversely, children with parents abroad and separated/divorced show a significant increase in their psychological distress when compared with children living with both parents. When adding children's demographics, family characteristics, living conditions, and the quality of school (Models 2-5), the significant effects of being in a transnational family with separated/divorced parents continue to be strong, and the value of coefficients increases. Tests for equality of coefficients were performed to compare the effects of parental migration when parents are together or separated/divorced. The test results were significant $\left(F=10.2^{* * *}\right)$ and indicate that there is a greater negative impact on children's psychological well-being when parents migrate and are separated/divorced than when parents migrate and are in a relationship.

The subsequent analysis presents six models, each including the complete set of control variables as defined in Model 5 in Table 2. Each model examines a particular characteristic of a transnational care arrangement. We discuss only results pertaining to the variable of interest, transnational family characteristics, because of space limitations.

Children whose father $(\beta=1.02)$ migrated overseas and who are living with their mother are more likely to experience lower levels of psychological well-being than children living with both parents (Model 6). Notably, no significant effects on well-being were observed when mother or both parents had migrated.

The results in Model 7 show that children with one or both parents away internally or internationally did not show poorer psychological outcomes than children in non-migrant families. Tests for equality of coefficients were conducted to compare the effects of internal and international migration on children's psychological 


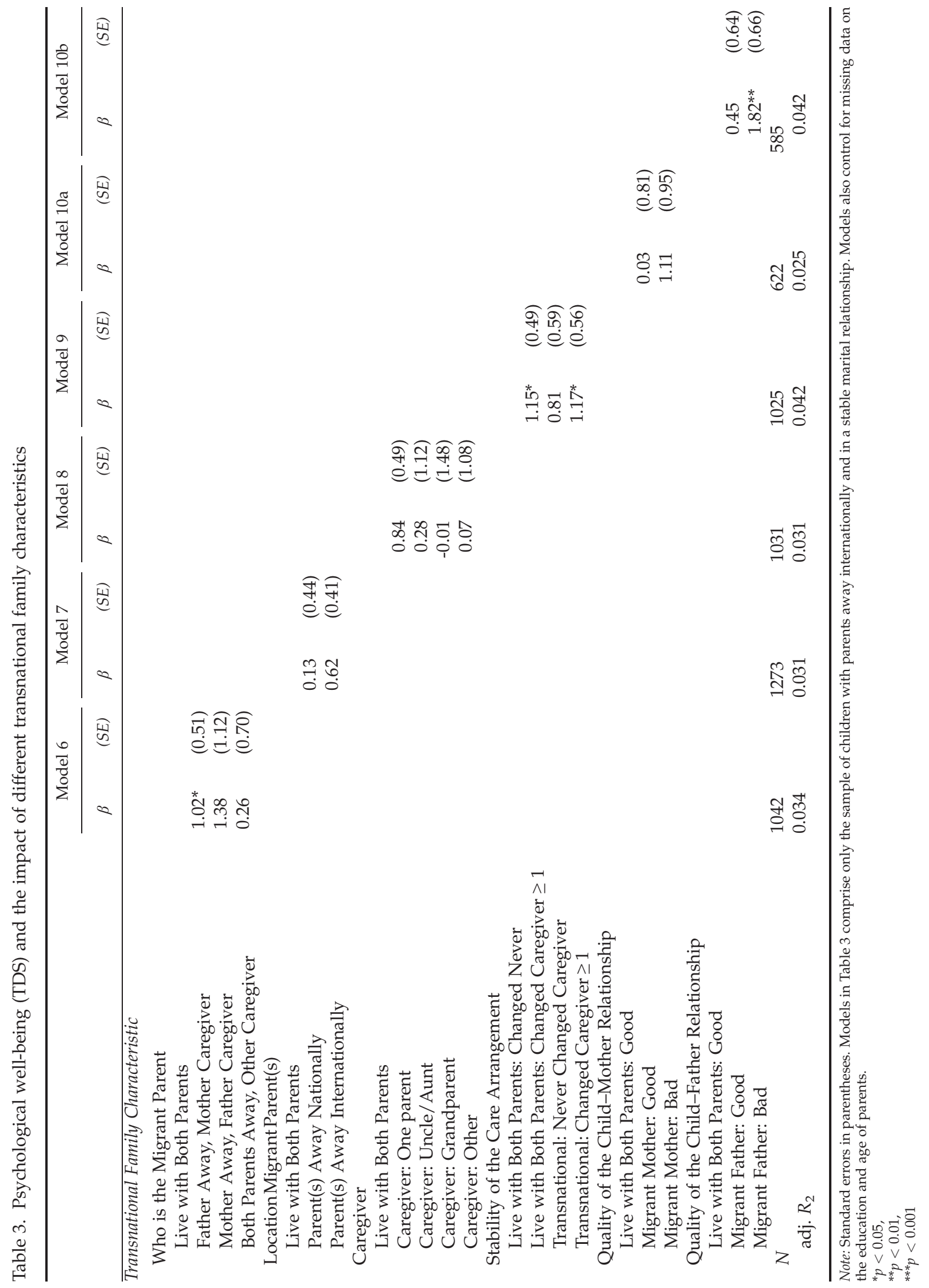


well-being. The results were not significant $(F=1.1)$, which imply that international parental migration has no differing impact on children's psychological well-being than internal parental migration, going against what we expected based on the literature.

Confirming our expectations for the Ghanaian context, Model 8 shows no significant difference in the psychological well-being of children cared for by a kin relative and children living with both parents. However, the low number of cases we had in the category of caregivers other than parents warrant some caution in interpreting these results.

A significant link exists between the frequency of change in the caregiver and more psychological difficulties among children (Model 9). Children of both transnational $(\beta=1.17)$ and non-transnational $(\beta=1.15)$ families who changed their caregiver once or more had a greater likelihood of psychological distress compared with children who never changed their caregiver and were living with both parents. Interestingly, children in transnational families who had never changed caregiver did not show any difference in well-being than children who lived with both parents and never changed caregiver.

There is no difference in well-being between children living in transnational families and children living with both parents in Ghana when the relationships with migrant mothers or fathers are good (Models 10a and 10b). Conversely, a bad relationship with a migrant father $(\beta=1.82)$ significantly affects the psychological well-being of the child compared with children living with both parents in good relationships. Notably, though, children with a bad quality relationship with migrant mothers do not show a differing impact on their psychological well-being than children living with both parents, thus only partially confirming our expectations.

\section{DISCUSSION}

Before discussing our findings, some limitations of this study should be noted. Sampling children in schools does not capture the possible effects of parental migration on children dropping out of school. It is nearly impossible to sample dropout children randomly because they are difficult to locate within the larger population. At the same time, sampling in schools facilitated the collection of children's perspectives, whereas most research on children relies on adult assessments. The survey was conducted in urban areas with high out-migration rates, and the results may not be applicable to those areas with lower migration rates. Another limitation is that we were unable to collect data on the length of separation between the child and the migrant parent. Children, and especially the younger ones, had difficulties remembering dates with accuracy related to their parent's departure. Finally, because of the cross-sectional nature of the data, important characteristics such as children's fostering histories, parental migration spells, or the changes in the psychological outcomes over time could not be accounted for. This field of study will therefore benefit from future research that collects longitudinal data to capture family life during the different stages of the life cycle (Wall \& Bolzman, 2014).

Despite these limitations, this study adds to current knowledge on the effects of transnational family life on the psychological well-being of children in three ways. First, overall, there are negligible differences in the well-being of children that live in transnational families compared with those that live with both of their parents in Ghana. This is different from the prevalently negative emotional outcomes documented in qualitative studies from the Philippines and South America. Second, contrary to what is argued by both qualitative and some quantitative studies, we find that mother migration is not associated with worse child psychological outcomes. Third, transnational families are diverse. This is one of the few quantitative studies to take different characteristics into account. These three contributions are discussed subsequently.

Why are there negligible differences between children living in transnational families and those living with both their parents? When we separate children who are in transnational families and have divorced/separated parents from those in transnational families whose parents are together and compare them with children in non-transnational families, we find no negative effect for children in transnational families whose parents are together. This indicates that negative results are driven by those families that are transnational and where parents are divorced/separated. These findings align closely with research conducted by Nobles (2011) in 
Mexico, demonstrating that parental migration in divorced and non-divorced families are substantially distinct experiences and that children in transnational families whose parents are divorced / separated are doing significantly worse in terms of their psychological well-being.

A further reason for the lack of significant differences between children in transnational families and non-transnational families relates to the normative context of social parenthood and child fostering in Ghana, which differs from Asian and South American contexts where transnational family studies have been conducted and where the nuclear family model is strong (Coe, 2011; Mazzucato \& Schans, 2011). In our sample, 16\% of pupils had at least one parent who migrated internationally, and 32\% had at least one parent who migrated internally within Ghana. These high percentages of school children not living with at least one parent due to migration highlight that in the urban research locations of our study, this phenomenon is common. This helps to explain why having a migrant parent is not stigmatised among Ghanaian children (Poeze \& Mazzucato, 2014). Furthermore, the high rates of child fosterage in Ghana, irrespective of migration, means that for some children, parental migration may not entail a change in caregiver, if they were already fostered prior to a parent's migration.

Another significant finding that runs counter to the literature is the lack of negative effects associated with the migration of mothers, when parents are in a relationship. Both quantitative and qualitative literatures argue that migration of mothers is associated with negative psychological outcomes for children (Liu et al., 2009; Parreñas, 2005; Wen \& Lin, 2012). Yet, our findings show, similar to Graham and Jordan (2011), no significant association between these two aspects when considering only cases of transnational families in which the parents are in a relationship. A small but significant negative association results when fathers migrate. We discuss three possible explanations for our findings: two methodological and one empirical. First, studies that emphasise the negative effects of maternal migration are primarily conducted with mothers (Bernhard et al., 2009; Parreñas, 2001), leaving children's perspectives relatively underresearched. Even when children are said to be the focus of research, the results primarily come from assessments of adults, be they caregivers or parents (Dreby, 2007; Pribilsky, 2001). Yet, children's assessments can differ significantly from those of adults (Jordan \& Graham, 2012). A second methodological point is that interviews capture how people experience and feel about being in a transnational family. When mothers cry, recounting how they miss their children or their frustrations and guilt about not seeing them grow up, they are expressing feelings about being in a transnational family. In surveys using psychological indicators, such as the one used in this study, questions are not embedded in a discussion about transnational families but are rather of a more general nature (e.g. do you feel angry and do you have friends). These two methods, equally justified, capture different components of transnational family living (Mazzucato, 2015). In our case, the absence of significant negative psychological effects on children in transnational families does not mean that children do not miss their mothers or fathers, but rather that these emotions that they may have do not interfere with their psychological development.

A third reason that our findings may differ from the literature is empirical: divorce or problematic marriages may be more likely in transnational families where women migrate. As we have found that divorce leads to worse outcomes for children in transnational families, studies arguing that mothers' migration is worse for children may be conflating the two issues of divorce/separation and mother migration. In an investigation of prevalence of divorce among Ghanaian migrants in the Netherlands and the UK, Caarls and Mazzucato (2015) find that divorce is not more prevalent among couples who migrate except when women migrate alone. These results taken together with our findings indicate that poorer child well-being in motheraway families may actually be a reflection of the fact that mothers' migration more often takes place under conditions of spousal separation as compared with fathers' migration. Furthermore, the result in our study that even when couples are together, a father's migration is associated with slightly poorer child psychological wellbeing may indicate that there are troubled partnerships when women stay behind, but the latter are less able to divorce/separate because of their dependent position. They remain married to the migrant husband in the hope of receiving some help, even when the relationship is fraught with 
tensions and distrust, as found in Ghana (Manuh, 1999; Coe, 2011). This, again, attests to the importance of marital tension or separation in a transnational family and not the migration of a mother per se as detrimental to the child's wellbeing. More attention should be given in future research, in both large-scale and in-depth studies, to the conditions of transnational care arrangements when women migrate.

Our study looked at other characteristics of transnational families in order to take the diversity of transnational families into account. We find that children with a good relationship with their migrant mothers and fathers did not show significant differences in psychological wellbeing compared with those living with both parents in Ghana. This highlights the importance of maintaining a good parent-child relationship over long distances. Studies in the Philippines and China have shown how migrants maintain an active parenting role through information and communication technologies and that this has positive consequences for the emotional well-being of children (Madianou \& Miller, 2011; Wen \& Lin, 2012). Furthermore, frequent contact between migrant parents and children was found to be significantly associated with African migrant parents' positive evaluations of their relationships with their children in the home country (Haagsman \& Mazzucato, 2014). Our data show that children with a good relationship with their parents are more likely to be in contact with their parents at least once a week and to see them physically, compared with children with bad relationships. One important area for policy makers and practitioners striving to improve the situation of the children of migrants is to facilitate communication and visits between migrant parents and their children to foster positive relationships.

The type of caregiver does not make a difference in psychological well-being. Yet, stability in the caregiving arrangement matters. Children who change from caregiver to caregiver show poorer psychological well-being than children who stay with the same caregiver. Initiatives that cater to transnational families would be well served to work with parents before they migrate, to ensure that the person with whom they leave their child will be able to care for him or her for the medium to long term. These could be initiatives in the form of information to parents on what they need to think about before migrating

Copyright @ $@ 2016$ John Wiley \& Sons, Ltd. as well as state-level child care subsidies or grants for caregivers who stay in the origin country.

International migration is not associated with poorer psychological outcomes compared with internal migration. Children with international migrant parents communicated more frequently with their parents via cellular phone than internal migrants. The latter however had more frequent face-to-face contact with their parents. The use of communication technologies by international migrants may help maintain the parent-child relationship and compensate, to a certain extent, for the physical absence of parents over time as has been argued by studies in the Philippines on parent-child communications (Madianou \& Miller, 2011). The availability of communication technologies calls into question theories that presume geographical proximity as a prerequisite for meaningful family relationships such as attachment theory (Bowlby, 1973) that continues to be used in much work on child psychology (Suarez-Orozco et al., 2002).

In summary, our study is one of the first largescale studies to take into account the variety of forms that transnational families take, and it is the first to do so in the African transnational context. By combining insights from small-scale transnational family studies, with insights from child psychology and family sociology, this study is able to show how different characteristics of transnational family life are of relevance for children's psychological well-being. These findings are of use to programmes interested in designing interventions to assist migrant parents and their families back home to ensure that the well-being of children is maintained across large distances.

\section{ACKNOWLEDGEMENTS}

The research presented in this article was conducted as part of the Transnational Child-Raising Arrangements between Ghana and The Netherlands (TCRA) project funded by the Netherlands Organization for Scientific Research, WOTRO Science for Development Division (WOTRO/NWO grant number W01.65.316).

\section{REFERENCES}

Amato PR, Cheadle J. 2005. The long reach of divorce. Journal of Marriage and Family 67: 191-206.

Popul. Space Place 2017; 23: e2004 DOI: $10.1002 / p s p$ 
Bernhard JK, Landolt P, Goldring L. 2009. Transnationalizing families. International Migration 47: 3-31.

Bowlby J. 1973. Separation, Anxiety and Anger. Basic Books: New York.

Boynton-Jarrett R, Hair E, Zuckerman B. 2013. Turbulent times: effects of turbulence and violence exposure in adolescence on high school completion, health risk behavior, and mental health in young adulthood. Social Science E Medicine 95: 77-86.

Bzostek SH, Beck AN. 2011. Familial instability and young children's physical health. Social Science $\mathcal{E}$ Medicine 73: 282-292.

Caarls K, Mazzucato V. 2015. Does international migration lead to divorce? Population 70: 127-151.

Case A, Fertig A, Paxson C. 2005. The lasting impact of childhood health and circumstance. Journal of Health Economics 24: 365-389.

Coe C. 2011. What is the impact of migration on transnational family life? American Ethnologist 38: 148-163.

Constable N. 2003. A transnational perspective on divorce and marriage. Identities 10: 163-180.

Dankyi E, Mazzucato V, Manuh T. 2016. Global social protection as a reciprocal process. Oxford Development Studies doi: 10.1080/13600818.2015.1124078.

Dreby J. 2007. Children and power in Mexican transnational families. Journal of Marriage and Family 69: 1050-1064.

Dreby J. 2010. Divided by Borders: Mexican Migrants and Their Children. University of California Press: Berkeley.

Faist T, Bilecen B, Barglowski K, Sienkiewicz J. 2015. Transnational social protection. Population, Space and Place 21: 193-202.

Fan F, Su L, Gill MK, Birmaher B. 2010. Emotional and behavioral problems of Chinese left-behind children. Social Psychiatry and Psychiatric Epidemiology 45: 655-664.

Fog Olwig K. 2014. Migration and care: intimately related aspects of Caribbean family and kinship. In Transnational Families, Migration, and Care Work, Baldassar L, Merla L (eds). Routledge: Oxford.

GDHS. 2008. Ghana Demographic and Health Survey 2008.

Glick JE. 2010. Connecting complex processes. Journal of Marriage and Family 72: 498-515.

Goodman R. 1997. The Strengths and Difficulties Questionnaire. Journal of Child Psychology and Psychiatry 38: 581-586.

Goodman R, Ford T, Simmons H, Gatward R, Meltzer H. 2000. Using the Strengths and Difficulties Questionnaire (SDQ) to screen for child psychiatric disorders in a community sample. The British Journal of Psychiatry 177: 534-539.

Goody E. 1982. Parenthood and Social Reproduction: Fostering and Occupational Roles in West-Africa. Cambridge University Press: Cambridge.

Graham E, Jordan LP. 2011. Migrant parents and the psychological well-being of left-behind children in
Southeast Asia. Journal of Marriage and Family 73: 763-787.

Haagsman K, Mazzucato V. 2014. The quality of parent-child relationships in transnational families. Journal of Ethnic and Migration Studies 40: 1677-1696.

Jordan LP, Graham E. 2012. Resilience and well-being among children of migrant parents in South-east Asia. Child Development 83: 1672-1688.

King R, Cela E, Fokkema T, Vullnetari J. 2014. The migration and well-being of the zero generation. Population, Space and Place 20: 728-738.

Liu Z, Li X, Ge X. 2009. Left too early. American Journal of Public Health 99: 2049-2054.

Madianou M, Miller D. 2011. Mobile phone parenting: reconfiguring relationships between Filipina migrant mothers and their left-behind children. New Media $\mathcal{E}$ Society 13: 457-470.

Manuh T. 1999. This place is not Ghana. Ghana Studies 2: 77-95.

Mazzucato V. 2011. Reverse remittances in the migration - development nexus. Population Space and Place 17: 454-468.

Mazzucato V. 2015. Transnational families and the wellbeing of children and caregivers who stay in origin countries. Social Science \& Medicine 132: 208-214.

Mazzucato V, Schans D. 2011. Transnational families and the well-being of children. Journal of Marriage and Family 73: 704-712.

Mazzucato V, Cebotari V, Veale A, White A, Grassi M, Vivet J. 2015. International parental migration and the psychological well-being of children in Ghana, Nigeria, and Angola. Social Science and Medicine 132: 215-224.

Nobles J. 2011. Parenting from abroad. Journal of Marriage and Family 73: 729-746.

Palmieri PA, Smith GC. 2007. Examining the structural validity of the Strengths and Difficulties Questionnaire (SDQ) in a U.S. sample of custodial grandmothers. Psychological Assessment 19: 189-198.

Parreñas RS. 2001. Servants of Globalization: Women, Migration and Domestic Work. Stanford University Press: Stanford.

Parreñas RS. 2005. Children of Global Migration: Transnational Families and Gendered Woes. Stanford University Press: Stanford.

Peil M. 1995. Ghanaians abroad. African Affairs 94: 345-67.

Poeze M, Mazzucato V. 2014. Ghanaian children in transnational families: understanding left-behind children's experiences through local parenting norms. In Transnational Families, Migration, and Care Work, Baldassar L, Merla L (eds). Routledge: Oxford.

Pribilsky J. 2001. Nervios and 'modern childhood'. Childhood 8: 251-273.

Pribilsky J. 2004. 'Aprendemos a convivir': conjugal relations, co-parenting, and family life among 
Ecuadorian transnational migrants in New York City and the Ecuadorian Andes. Global Networks 4: 313-34.

Schmalzbauer L. 2004. Searching for wages and mothering from afar. Journal of Marriage and Family 66: 1317-1331.

Smith RC. 2006. Mexican New York: Transnational Lives of New Immigrants. University of California Press: Berkeley.

Smith A, Lalonde RN, Johnson S. 2004. Serial migration and its implications for the parent-child relationship. Cultural Diversity and Ethnic Minority Psychology 10: 107-122.

Suarez-Orozco C, Todorova IL, Louie J. 2002. Making up for lost time. Family Process 41: 625-643.
Wall K, Bolzman C. 2014. Mapping the new plurality of transnational families: a life course perspective. In Transnational Families, Migration, and Care Work, Baldassar L, Merla L (eds). Routledge: Oxford.

Wen M, Lin D. 2012. Child development in rural China. Child Development 83: 120-136.

\section{SUPPORTING INFORMATION}

Additional supporting information (Tables S1 and S2) may be found in the online version for this article at the publisher's web site. 